\title{
Mainstream and formal epistemology
}

\author{
VINCENT F. HENDRICKS \\ Cambridge: Cambridge University Press, 2006, xii +188 or.
}

Vincent F. Hendricks Roskilde Unibertsitateko irakaslea da eta Filosofia formala irakasten du; azken urteotan epistemologian (formala hau ere) egin du lan eta zenbait aldizkariren editorea da. Ezagunak dira $\Phi$-LOG eta The Network for Philosophical Logic and Its Applications, logika eta filosofia formalari zuzendutako aldizkaria eta sarea, hurrenez hurren. Orain, eta izenburuak dioen moduan, epistemologiari liburua eskaintzen dio, bai ohiko epistemologiari, bai epistemologia formalari. Bere lanaren berehalako ondorioa dela esan dezakegu, non ikuspegi klasikoa eta ikuspegi formala elkartuko dituen proposamena egiten duen. Bere iritzian, epistemologia mota bi horiek ez daude orain arte kontsideratu izan diren bezain urrun. Ikuspegi metodologiko batetik bada zerbait garrantzitsua partekatzen dutena, eta honako hauxe izango da liburuaren ildo nagusia: «forcing» froga metodoaren erabilera, aurrerago azalduko dena.

Has gaitezen lehenik Hendricksek duen epistemologiaren ideia aurkezten. Ezagutzaren aroan bizi gara, pasioa sortzen omen du ezagutzak guregan eta, batez ere, gure buruzagitza intelektual eta politikoan. Egia da ez ginatekeela garena izango mendeetan gizakiok ezagutzaren etengabeko bilaketan eta azterketan arituko ez bagina. Ezagutza funtsezkoa da denetarako: deliberazioan, erabakian eta ekintzan. Ezagutzaren azterketa sistematikoari eta zehatzari epistemologia deitu izan zaio beti Filosofian, eta ezagutzaren eskuratze irizpideak, ezagutzaren mugak eta ezagutzaren justifikazio moduak estudiatu izan ditu. Ezagutzaren beraren posibilitatea izan da tradizionalki epistemologiaren gakoetako bat, eszeptizismoa baita epistemologiaren amesgaizto nagusia. Horixe saihestea izan ohi da epistemologiak izan duen arazoetako bat, kontuan izanik akatsak egiteko zein joera dugun gizakiok. Horrek, akatsak egiteko posibilitate horrek, sostengatu du mendeetan zehar eszeptizismoa: akatsa egiteko aukera egonik, ez dago egiazkoa dena jakiterik. Ezin dugu, beraz, ezagutu, ezagutzaren definizioak ezagutua dena egiazkoa izatea exijitzen baitu. Horrela izan da mendeetan. Platonek Thaetetus eta Menon elkarrizketetan, Kantek bere Arrazoimen hutsaren kritika liburuan eta gertuago, C.I. Lewisek bere lanetan, adibidez, ezagutzaren definizioa hiru ezaugarri nagusitan oinarritu izan dute: egia, ustea, justifikazioa. Hiru ezaugarri horiek, beharrezkoak direnak banan- 
banan hartuta eta nahikoak elkarrekin jarrita, ezagutzaren definizio klasikoa eta estandarra osatzen dute: egiazko uste justifikatua.

Eskuliburu modura pentsatua egonik ere, eskuliburu gehienen izaera deskribatzailetik harago doa Hendricksen lan hau, proposamen zehatz bat aurkezten duelako. Liburuaren helburuetako bat da defendatzea deskribatuko diren epistemologia mota ezberdinak bateragarriak direla, edo behintzat, tresneria teoriko berdintsua erabiltzen dutela azpimarratzera zuzendua dago. Hendricksek ardatz metodologiko berdintsua ikusten du, epistemologia ezberdinak bateratuko lituzkeena. Tresna teoriko hori P. Cohen matematikariaren «forcing» froga metodoa da. Kontsistentzia frogatzeko teknika oso berezia da. Zehazkiago, multzo teoriak axiomekiko continuumaren hipotesiaren eta hautapen-axiomaren kontsistentziaren frogan irekitako bide berria, beste eremu formaletara arrakastaz zabaldu dena. Hainbat modutan erabil daiteke teknika hori. Horietako bat objektuen eraikuntzan oinarritzen da, propietate bereziko objektuen eraikuntzan. Beste moduak alderantziz jokatzen du, ereduak eraikitzen ditugu non propietate bereziren bat duten objektuak existitzen ez diren, horrela «behartzen» dugu guk nahi duguna, objektua eraikiz edo desagerraraziz. Horrela, «forcing»a, Hendricksen ustez, tesi epistemologikoa baino gehiago printzipio heuristikoa da, estrategia bat. Bide hori jarraituz, hutsegite aukerak garrantzirik gabekoak direla erakusten dugu.

Nola sar daiteke ideia hori epistemologian? Nola ulertu? Nolako erabilera du? Eszeptizismoa saihesteko modu gisa aurkezten digu Hendricksek «forcing» metodoaren erabilera. Egilearen arabera, eszeptikoen argudioen kontra jarraitutako estrategiek betidanik erabili ohi dute halako metodo bat ezagutzaren ezintasunaren tesiaren aurka. Eszeptizismoaren tesi horren funtsa hutsegitean datza: edozein testuinguru eta egoeratan, ezagutza ez da posible hutsegite aukerak daudelako. Eszeptizismoaren argudio nagusiak bi dira: azpideterminazioa eta indukzioa. Horietako lehenak, teorien eta ebidentzien arteko erlazioa esplotatzen du erabakiezintasuna azaleratzeko. Hau da, teoria bat edo uste bat erabakiezina da (bere egiaren estatusarekiko, noski) emandako ebidentzien arabera, baldin eta gutxienez bi teoria badira elkarrekiko inkonsistenteak izanik, ebidentziekiko kontsistenteak direnak. Esan nahi dena honako hauxe da: bi azalpen bateraezinak baditugu ebidentziak esplikatzeko. Bigarren argudioa indukzioaren arazo famatua da, aski ezaguna. Hendricksen arabera, hutsegite aukera horiek baztertzea da berak proposatzen duen metodoaren estrategia, aukera horiek minimoak direla erakusten duelako, espekulatiboak edota hutsalak. «Forcing»a deitzen dio, Cohenen intuizio bera jarraitzen duelako.

Esan bezala, eskuliburu bat da, eta 9 kapitulutan banatua dago. Lehenengoa, sarrera izanik eta bigarrena, prestaketarako testuinguru kontzeptuala aurkezteko, zazpi geratzen dira epistemologia mota ezberdinak aurkezteko: ko- 
rronte nagusia, kontrafaktikoa, testuinguru-epistemologia, logikoa, konputazionala, Modala eta «pletorikoa» edo oparoa. Horietatik lehenengo hirurak korronte klasikoaren inguruko teoriak dira; eta besteak, aldiz, epistemologia formalak.

Epistemologia klasikoaren korronte nagusiak, modu informalean, azterketa kontzeptuala eta espekulazioa erabili izan ditu ezagutzaren azterketan. Eta horrela da oraindik zenbait testuinguru akademikotan. Ikuspegi horretatik aldenduz, beste tradizio batek ezagutzaren azterketa formalari eskaini dio arreta logikaren tresna eta metodoak erabiliz; eta, azken urteotan, konputazioaren teoriatik eta probabilitatearen teoriatik jaso izan dira, baita ere, baliabide teoriko eta formalak.

Liburu honetan, egileak bi ikuspegien bateragarritasuna defendatzen du, bi tradizio edo abordatze era ezberdin horiek ez direla bateraezinak eta badutela elkarren artean lotura eta erlazioa, gaur egun arte pentsatu izan den baino handiagoa dena gainera. Ondorengo kontzeptuak erabiliko ditu konparaketa egiteko: ezagutzaren izaera modala, hutsezintasuna, forcinga eta eszeptizismoari ematen zaion erantzuna; ezagutzaren indarra eta baliozkotasuna; fidagarritasuna; eta lehen eta hirugarren pertsonen arteko ikuspegien bereizketa.

Ezagutzaren nozio gehienak modalak dira, hau da, benetako gertaera egoerarekiko ezberdinak diren beste gertaera egoerekiko definitzen da ezagutza. Logikan egoerak edo mundu posibleak deitzen dira gertaera egoera ezberdin horiek. Ez dakigu dena, ez dakigu mundua benetan nolakoa den egoera bakoitzean, ez gara iristen guztia jakitera, gerturatzeak besterik ezin ditugu egin. Horrelako baldintzetan, nola da posible ezagutza? Zer da? Platonek idatzitakoaren arabera eta egun oraindik estandarra kontsideratzen den ikuspegia honako hau da: justifikatutako egiazko ustea. Formalismoak azkeneko bi ezaugarriak bakarrik kontsideratu izan ditu historikoki eta horien araberako 'argazkia' eraiki du mundu posibleen semantikaren bitartez. Egoera bakarra da benetakoa baina ezagutezina bere osotasunean. Hainbat uste ditugu munduko gertaerei buruzkoak, batzuk egiazkoak dira, beste batzuk faltsuak. Egiazko uste horiek osatzen dute gure ezagutza corpusa, horrela izendatzerik bada ezagutzen duguna. Horrek ez du mundua guztiz 'ezagutzen' edo irudikatzen. Mundua osatzeko gure beste usteak behar izaten ditugu eta, zalantzazkoak izanik, munduaren irudikatze ezberdinak posible egiten dituzte. Posibilitate ezberdin horiek dira mundu posibleak. Beraz, ezagutzen duguna egiazkoa da kontsidera ditzakegun gertaera egoera edo mundu posible guztietan.

Epistemologian korronte nagusiak ezagutzaren jabetzarako baldintza beharrezkoak eta nahikoak bilatzen ditu. Horixe jorratzen da hirugarren kapituluan. Adibide eta kontra-adibide arruntak erabiliz, ezagutza justifikatzeko ditugun arrazoiak gutxiesteko arrazoien bila dihardu. Fidagarritasun epistemikoa da helburua. Arrazoiek iraunkorrak behar dute izan, hau da, egian oinarritu- 
takoak eta akatsa saihesten dutenak, baldin uste fidagarriak lortuko baditugu. Baina fidagarritasun epistemikoa oso kontzeptu zalantzazkoa da, eztabaidatua, onartzen baitu egiazko ustea (justifikaziorik gabekoa) ezagutzatzat har daitekeela, baldin eta bere ekoizpenean erabilitako prozedurek fidagarritasun nahikoa sortzen badute. Fidagarritasun hori aurreko erabilerekin alderatuta egia/faltsua ratioaren arabera neurtzen da. Hau da, indukzioaren arazora bueltatzen gara berriro.

Laugarren kapituluan, epistemologia formaletara pasatzen gara. Epistemologia kontrafaktikoa logika modaleko kontrafaktikoen azterketetan oinarritzen da, mundu posibleen semantikaren tresneria guztia erabiliz, Stalnaker, D. Lewis eta beste hainbaten lanak jarraituz. Egiaren aurkikuntza prozesu baten modura, akatsak saihestuz eta egia eraikiz, benetako mundutik gertuen dauden mundu posible guztietan egiazkoa dena da ezagutza. Oso gertutik ikusita, bosgarren kapituluak, Lewisen testuinguru-epistemologia aurkezten du. Norbaitek zerbait ezagutzen du baldin dituen ebidentziek ezagutzen duenaren aurkakoa izatearen posibilitate guztiak baztertzen badituzte. Aurrekoaren eta ondorengoaren garapenak dira. D. Lewisen ekarpenak ez dira kapitulu honetara mugatzen.

Epistemologia logikoa (zer ote ziren ba aurreko biak?) logika epistemikoa da. Estatus berezia omen du. Logika epistemiko klasikoak eta mundu posibleen semantikak osatzen dute ikuspegi hori. Baina ezagunak dira ikuspegi klasiko horretako mugak. Alde batetik, justifikazioaren kontzeptuari ez ikusiarena egitea eta, bestetik, uste eta ezagutzen dinamika berrien tratamendu eskasa. Aipatu muga horiek nolabait epistemologia konputazionalaren bitartez gaindi daitezkeela, zazpigarren kapituluan azaltzen den moduan. Epistemologia konputazionalak, logikaz gain, ikaskuntzari buruzko kontsiderazioak sartzen ditu jokoan eta, horrela, ezagutzaren dinamikaren prozesua aztertzea beharrezkoa da: ezagutza berriak aurreko corpusean sartzerakoan nolako eragina duten bai ezagutza zaharretan bai horietatik deribatutako usteetan (batzuk faltsuak izan baitaitezke). Ikuspegi formala alde batera utzi gabe, eragile modalen epistemologia aztertzen da zortzigarren kapituluan. Logika epistemikoaren (orokorrean esanda, modalaren) eta mundu posibleen semantikaren inguruan, logika epistemikoa hedatzen da eragile denboralak eta eragile modalak konbinatuz. Logikaren hibridazioa.

Azkeneko kapitulua ondorioei eskainia dago. Epistemologiaren oparotasun edo ugaritasun horren aurrean Hendricksek proposatutako ikuspegi orokorraren eta bateratzailearen defentsa egiten du funtsezko bi oinarritatik abiatuta. Lehenengoa metodologikoa da: forcing-a. Bigarren oinarria elkarreragiketa da. Adibideen bitartez erakusten du ikuspegi klasikoaren korronte nagusiaren eragina epistemologia formal ezberdinetan, eta baita alderantzizkoa ere. 
Bukatzeko, esan beharra dago liburua atsegingarria eta interesgarria gertatzen dela, bereziki epistemologiaren egungo egoera ezagutu nahi duenarentzat, baina baita eguneroko eztabaidetan agertzen zaizkigun zalantzak argitzeko argudioak bilatu nahi dituenarentzat ere. Hau da, gaur egun hain zabaldua dagoen justifikatu gabeko doxa saihestu eta salatu nahi duenarentzat abiapuntu erabilgarria da benetan, ikuspegi zabala eta, aldi berean, homogeneoa edo lerrotua eskaintzen duena, bibliografia zabal eta eguneratuarekin.

Xabier Arrazola

ILCLI 